\title{
The Effect of Leader-Member Exchange on Innovative Work Behavior in the Saudi Hospitality
}

\author{
Abdulrahman Alsughayir ${ }^{1}$ \\ ${ }^{1}$ School of Economics \& Administrative Science, Al Imam Muhammad ibn Saud Islamic University, Riyadh, \\ Kingdom of Saudi Arabia \\ Correspondence: School of Economics \& Administrative Science, Al Imam Muhammad Ibn Saud Islamic \\ University, Riyadh 11431, KSA. Tel: 966-11258-5555. E-mail: dr.imamabd@yahoo.com
}

Received: April 10, 2017

doi:10.5539/ijbm.v12n6p189
Accepted: May 12, 2017

URL: https://doi.org/10.5539/ijbm.v12n6p189

\begin{abstract}
This study investigated whether a relationship exists between leader-Member exchange (LMX) and innovative work behavior (IWB) of hotel sector employees in the territory of Riyadh. LMX's overall effect on innovative employee work behavior can be seen in the values of $\mathrm{R}^{2}=0.655$ and adjusted $\mathrm{R}^{2}=0.423$. Overall, the results explain 65 percent of the variation in innovative employee behavior, which represents a satisfactory and positive result for the study and supported the study's hypotheses. One aim of the study was to improve our understanding of the effect that LMX has on IWB among the hospitality sector in Riyadh. LMX was found to be an important antecedent of IWB, and a high level of quality of LMX between employees and supervisors will inspire employees to be increasingly innovative while working.
\end{abstract}

Keywords: leader-member exchange, innovative work behavior, hospitality sector, Saudi Arabia

\section{Introduction}

Innovation has been widely accepted as being important for organizational effectiveness (Yuan \& Woodman, 2010). It has been argued that being able to constantly innovate services, products, work processes, and technologies is crucial for private-sector organizations looking for a competitive advantage (De Jong \& Den Hartog, 2010). In today's competitive and rapidly changing environment, organizations face increasing pressure to engage in innovative behaviors in order to create and deliver new products and gain a sustainable competitive advantage. Consequently, organizations are increasingly relying on their employees to be innovative (Ramamoorthy et al., 2005). For instance, Getz and Robinson (2003) found that employees initiated 80 percent of the ideas in one organization. Despite this, it is rare for employees to be formally asked to innovate. Therefore, it is unusual that employees will be rewarded, either directly or explicitly, for behaving in an innovative manner (George \& Brief, 1992; Katz, 1964).

There is more to innovation than simply thinking of good ideas; it also involves making ideas actually work, both in a technical sense and a commercial sense. West and Farr (1989, p. 16) defined innovation as "the intentional introduction and application within a role, group or organization of ideas, processes, products or procedures, new to the relevant unit of adoption, designed to significantly benefit role performance, the group, the organization or the wider society." Luecke and Katz (2003, p. 2) defined innovation as "the successful introduction of a better thing or method." According to Akram et al. (2016), technological advance, global competition, and changes to basic regulations have made it very difficult for organizations to compete successfully in the contemporary business world; therefore, organizational survival in a market-oriented economy is dependent on continuous innovation. Agarwal (2014, p. 580) claimed that organizations in general are increasingly examining the factors that increase their employees' innovative work behavior (IWB). Failure to make changes could overwhelm employees, potentially leading to increased absenteeism, resignations, poor morale, and decreased customer service levels (Subramony \& Holtom, 2012). Organizations looking to increase their value creation, with the aim of sustaining long-term survival and success, must instill a mindset of innovation among their employees (Prahalad \& Ramaswamy, 2012).

The hospitality sector has becoming increasingly important in the countries of the Gulf Cooperation Council (GCC). The economies of these countries have historically been very dependent on oil. In recent decades, however, the region has undergone some significant economic changes as governments have increased their 
focus on non-oil sectors. The increase in tourism has been the main driver for the rise of the hospitality sector in these countries. According to the Saudi Hospitality Sector Report (2015), accommodation represents almost one-third of total tourist spending. As of the end of 2013, there were 458,045 hotel rooms in the region, with Saudi Arabia representing the largest share (63.6 percent). Saudi Arabia also added the most hotel rooms of any GCC country $(95,627)$, which represents a compound annual growth rate of 9.5 percent.

Saudi Arabia's hospitality sector is expected to provide approximately 300,000 jobs. The Human Resource Development Fund (Hadaf) offers material support to young job-seekers in this sector, while the average employment rate for women in the hospitality sector is a mere 2 percent. Therefore, in order to maintain developing innovations, as a way of ensuring continuity and keeping pace with economic developments, Saudi Arabia must view the hospitality sector as an innovative and strategic industry, especially at the individual level. IWB will make a huge contribution to enhancing the innovation level in Saudi Arabia. There is a glaring lack of research regarding Saudi Arabia's hospitality sector and the IWB of knowledge workers in that country. With a focus on the hotel sector, the aim of the present study was to examine whether a relationship exists between LMX and employees' IWB.

\section{Literature Review}

\subsection{Innovative Work Behavior}

West and Farr (1989) defined innovation as "intentional introduction and application within a role, group or organization of ideas, processes, products or procedures." De Jong and Den Hartog $(2007$, p. 8$)$ defined IWB as "the intentional behavior of an individual to introduce and/or apply new ideas, products, processes, and procedures to his or her work role, unit, or organization." According to Oukes (2010, p19), "Organizations that have the capability to innovate are better able to gain sustainable competitive advantage over their competitors." Employees who engage in innovative behavior develop ideas that would otherwise not be developed, and then carry, react to, and modify these ideas. Thus, employees are crucial when innovating products, processes, and methods within an organization (Ramamoorthy et al., 2005).

IWB ranges during the process from the initiation of an innovation to its implementation (De Jong \& Den Hartog, 2007). IWB is distinct from creativity, which is more limited and focuses solely on discovering and generating ideas. Also, IWB is broader than proactive work behavior (Crant, 2000; Parker, Williams \& Turner, 2006), which concentrates on implementing change, but does not specifically cover the initiation element of the innovating process. Although IWB does benefit the organizations, it is performed in a discretionary manner and may not be rewarded in a direct or formal sense (Agarwal, 2014). Such behavior encourages innovation once it is recognized as a norm within the organization (Martins \& Martins, 2002).

\subsection{Leader-Member Exchange}

Graen and Dansereau first introduced the leader-member exchange (LMX) theory in the 1970s. The theory has been defined as the quality of an interpersonal exchange relationship between an employee and his/her supervisor, and involves interdependencies and mutual influence (Graen, 1976; Uhl-Bien, 2006). LMX is based on social exchange theory, a basic tenet of which is that individuals provide benefits to other individuals in the expectation that they will receive equivalent-value benefits in return (Blau, 1964). LMX, which has been described as the social exchange between subordinates and higher-ups of both tangible and intangible resources, clearly identifies the different types of relationships that leaders have with individual employees (Bernerth et al., 2015). Graen (1976) and Graen and Scandura (1987) suggested that leaders may provide subordinates with benefits and resources including discretion latitude, recognition, rewards, and information. Those subordinates who have high-quality relationship with their leaders are referred to as in-group members, while those who have low-quality relationships are known as out-group members (Graen and Scandura, 1987; Sherman et al., 2012). Most early studies considered LMX as a single-dimension construct that varies from low to high quality (Jing-Zhou \& Wen-Xia, 2011).

\subsection{Relationship between LMX and IWB}

According to the theory, the relationship between a leader and an employee will improve over time, from low leader-member exchange to high. A higher-quality relationship will make it more likely for employees to behave innovatively. Several studies have confirmed this positive effect of LMX on individual innovation (Stoffers \& Heijden, 2009; Scott \& Bruce, 1994).

Most studies of the relationship between LMX and IWB have confirmed that the former has a positive effect on the latter (Altunoglu \& Gurel, 2015; Kheng et al., 2013) and that LMX is an important antecedent of IWB (Xerri, M., 2013, Agarwal, 2014). A high level of LMX quality between employees and supervisors will encourage 
greater innovativeness among employees when performing their job. When supervisors demonstrate supportive practices, there is a greater likelihood that IWB being successful and employees will probably be more confident about the chances of their innovative behavior resulting in performance (Yuan \& Woodman, 2010).

However, some studies have found that LMX did not have a significant influence on IWB (Taştan \& Davoudi, 2015). Bernerth et al. (2015), and Liden et al. (2006), all concluded that no relationship exists between LMX and performance. In a Singaporean context, Lee (2008) found that the LMX quality did not affect the IWB of R\&D professionals and therefore concluded that high-quality LMX does not have a positive impact on innovativeness. Similarly, Taştan and Davoudi (2015) argued that LMX quality did not affect the IWB of employees in various Turkish sectors. Albarq (2014) stated when transferred to another culture, the nature of evaluation and normative influence may vary from the measurements prescribed by a given theory.

\subsection{Theoretical Framework and Hypotheses}

On the basis of above discussion in literature review and because of these inconsistent findings, it is necessary to study this relationship in greater depth regarding the Saudi hospitality sector, and this relationship is provided in conceptual framework of study in Figs. 1. Accordingly, this research hypothesized that: LMX has a significant positive relationship with IWB among workers in the Saudi hospitality sector.

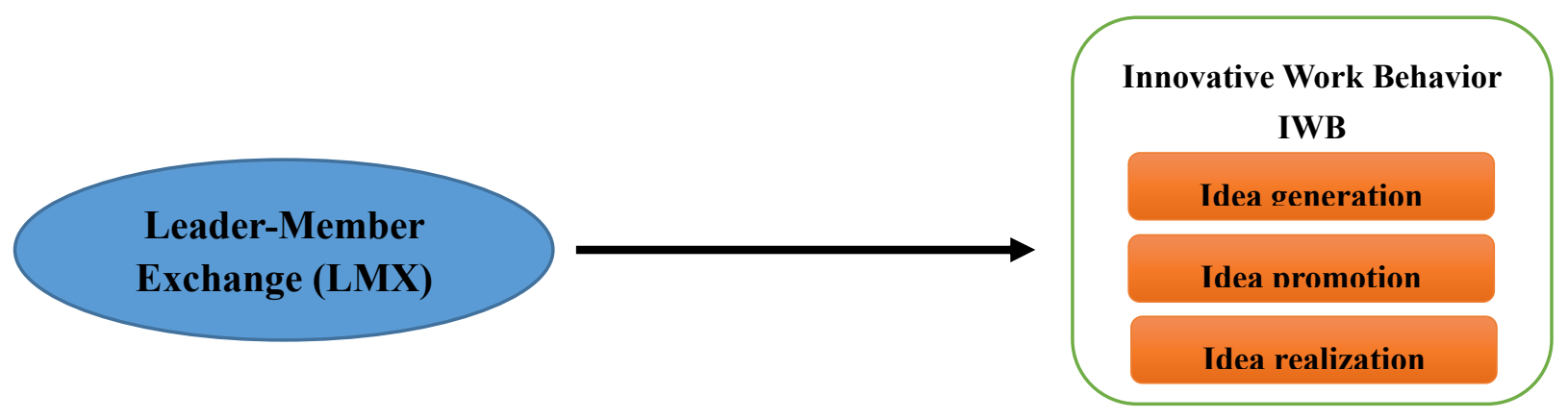

\section{Method}

Figure 1. Conceptual framework.

\subsection{Sampling Techniques}

Because it was not possible to gain accurate data regarding the size and location of this population, it was not appropriate to use probabilistic sampling techniques, so we used the non-probability convenience sampling technique instead to collect data. This technique was also used due to limits on accessibility and budget, and also in order to gain high-quality responses from the employees who were willing to complete the questionnaire in a timely manner. Based on Krejcie and Morgan's (1970) table for sampling, the sample size was 384 workers.

\subsection{Data Collection Method}

We conducted the study among employee/supervisor pairs working in 52 hotels in the Saudi Arabian capital of Riyadh. The employees' job positions varied among the middle and higher occupational levels. The employees were given information about the study's objective and anonymity, and were asked to self-administer and complete a questionnaire. The data were gathered in December 2016 and March 2017.

\subsection{Measurement}

The questionnaire was made up of seven items to assess LMX in three dimensions - trust (two items), respect (two items), and obligation (two items) - and also one global item that addressed relationship quality. Participants rated each of these seven items on a five-point Likert scale that ranged from 1 (not at all) to 5 (extremely). In order to measure employee IWB, we used the innovative work behavior scale developed by Janssen (2000). The three dimensions on this scale are idea generation, idea promotion, and idea realization and each dimension contains three items, with a reported alpha reliability of 0.94 (Janssen, 2000). All items were scored using a five-point Likert scale that ranged from 1 (never) to 5 (always). The variables were originally constructed in English and then translated to Arabic. I used the translation-back-translation methodology to heighten the linguistic quality and to establish conformity of meaning. In order to assess the efficiency of the Cronbach's coefficient alpha test, we conducted a pilot test was conducted on a convenience sample of 24 participants from the target sample. The result of 0.879 is above 0.70 - the acceptable cut-off value (Hair et al., 
2006). The pilot test data was excluded from the final analysis. For each factor, we also measured the Kaiser-Meyer-Olkin (KMO) test and Bartlett's sphericity test. All statistical analysis was conducted in SPSS version 18 (SPSS Inc., Illinois, USA) and the significance level was set at $\mathrm{p}<0.000$ level.

\section{Results}

Out of the 384 distributed questionnaires, 271 were returned, although eight were not completed properly and were therefore excluded from the final analysis, representing a final response rate of 68.5 percent. Descriptive statistics can be found in Table 1. Idea generation, idea realization, and idea promotion had mean values of 4.34, 4.49 , and 4.27, respectively, while LMX had a mean value of 4.25 and total IWB had a mean value of 4.37 .

Table 1. Descriptive statistics of the variables $(n=263)$

\begin{tabular}{lcccc}
\hline Variables & Min. & Max. & Mean & Std. deviation \\
\hline Idea generation & 1 & 5 & 4.34 & 0.568 \\
Idea promotion & 2 & 5 & 4.27 & 0.575 \\
Idea realization & 2 & 5 & 4.49 & 0.583 \\
Total IWB & 1 & 5 & 4.37 & 0.461 \\
LMX & 2 & 5 & 4.25 & 0.464 \\
\hline
\end{tabular}

Linear regression analysis technique was used to examine whether the LMX had a set of predictor variable in predicting IWB. Table 2 presents the correlation analysis and suggests that each of the four regression models was significant at the $\mathrm{p}<0.000$ level. For LMX and the idea generation model, the values are $\mathrm{R}^{2}=0.526$ and adjusted $\mathrm{R}^{2}=0.273$. The values for $\mathrm{LMX}$ and the idea promotion model are $\mathrm{R}^{2}=0.501$ and adjusted $\mathrm{R}^{2}=0.248$. LMX and the idea realization model have values of $\mathrm{R}^{2}=0.630$ and adjusted $\mathrm{R}^{2}=0.392$. The dimensions of IWB also have a positive and significant correlation with each other.

Table 2. Pearson product-moment correlations between study variables

\begin{tabular}{lcccc}
\hline Scale & LMX & IWB idea generation & IWB idea promotion & IWB idea realization \\
\hline LMX & - & & & \\
IWB idea generation & $0.526^{* *}$ & - & - \\
IWB idea promotion & $0.501^{* *}$ & $0.657^{* *}$ & $0.524^{* *}$ & - \\
IWB idea realization & $0.630^{* *}$ & $0.577^{* *}$ & \\
\hline
\end{tabular}

Note: Correlation is significant at ** $\mathrm{p}<0.01$ (2-tailed).

The values of $\mathrm{R}^{2}=0.655$ and adjusted $\mathrm{R}^{2}=0.423$ indicate the overall effect that $\mathrm{LMX}$ has on total employee IWB. As can be seen in Table 3, all four regression models were significant at the $p<0.000$ level. By observing $b$ values, it can be seen that that relational leadership explains most of the variation in idea generation (52.6 percent), idea promotion (51.3 percent), and idea realization (79.4 percent). Overall, relational leadership explains 65.0 percent of the variation in employee IWB, which represents satisfactory and positive results for the present study and supports our hypotheses.

Table 3. Summaries of multiple regression analysis for LMX predicting idea generation, idea promotion, and idea realization and total IWB

\begin{tabular}{lcccccccc}
\hline Construct & $\mathbf{R}$ & Adjust $^{2}$ & $\boldsymbol{\beta}$ & $\mathbf{b}$ & S.E & F & $\boldsymbol{t}$ & $\boldsymbol{P}$ \\
\hline Dependent variables & & & & & & & \\
idea generation & 0.526 & 0.273 & 0.526 & 0.644 & 0.077 & 94.263 & 10.668 & 0.000 \\
idea promotion & 0.501 & 0.248 & 0.501 & 0.513 & 0.066 & 82.838 & 10.057 & 0.000 \\
idea realization & 0.630 & 0.392 & 0.630 & 0.794 & 0.073 & 161.888 & 13.694 & 0.000 \\
Total IWB & 0.655 & 0.423 & 0.655 & 0.650 & 0.058 & 184.070 & 14.541 & 0.000 \\
\hline
\end{tabular}

Note: $b=$ un-standardized coefficients, $S . E=$ standard error of variables, $b=$ standardized coefficients, $t=t$-statistic, $p=$ significance level. $R^{2}=R$ square. 


\section{Discussions and Conclusion}

Due to the speed of global innovation, many organizations have been forced to review the contribution that their employees make to innovation. The present study has sought to improve our understanding of the effect that LMX has on IWB in the hospitality sector in the Saudi capital of Riyadh. We found that LMX is an important antecedent of IWB and that high-quality LMX between employees and their supervisors encourages the former to be more innovative while doing their job. Suhaimi and Panatik (2016) made a similar point when they stated that most studies of the LMX-IWB have confirmed that the former has a positive effect on the latter. By contrast, however, some studies have concluded that LMX does not have a significant influence on employees' IWB (Taştan and Davoudi, 2015). Studies have shown that the inconsistency in the LMX-IWB relationship can be due to inconsistencies in the findings of previous studies. Therefore, work engagement has been proposed as an important mechanism in the relationship given its proven linkage with LMX and IWB (Agarwal, 2014; Taştan \& Davoudi, 2015; Suhaimi \& Panatik, 2016).

Employees responded more innovatively to higher job demand levels when they felt that their leaders were rewarding their efforts fairly (Janssen, 2000). Furthermore, the trust that is inherent in a high-LMX relationship provides a context that makes subordinates more comfortable about promoting and suggesting innovative ideas. The present study also contributes to the literature on the services sector, IWB, and LMX, all of which are quite limited in the context of Saudi Arabia. Accordingly, this study has provided insights into the hospitality sector, which has received little scholarly attention in Saudi Arabia.

The variables chosen in the present study have also been widely studied as drivers of innovation in many manufacturing and service-based companies; therefore, future studies could study other predictors in order to extend the list of IWB predictors. Further studies could test and confirm the mediating role that work engagement plays in the LMX-IWB relationship. Previous studies have shown that certain personal characteristics can influence innovative behaviors; future studies could also consider these characteristics in order to add to the present study.

\section{Acknowledgements}

The author is grateful to the hotels managers in Riyadh, who helped in distributing and collecting the questionnaires, and the faculty of economics \& administrative science department in Al Imam Muhammad ibn Saud Islamic University for their constructive discussions and opinions.

\section{References}

Agarwal, U. A. (2014). Linking justice, trust and innovative work behavior to work engagement. Journal of Personnel Review, 43(1), 41-73. http://dx.doi.org/10.1108/PR-02-2012-0019

Akram, T., Lei, S., \& Haider, M. J. (2016). The impact of relational leadership on employee innovative work behavior in IT industry of China. Arab Economic and Business Journal, 11(2), 153-161. http://dx.doi.org/10.1016/j.aebj.2016.06.001

Albarq, A. N. (2014). Industrial Purchase among Saudi Managers: Does Country of Origin Matter. International Journal of Marketing Studies, 6(1), 116-126. http://dx.doi.org/10.5539/ijms.v6n1p116

Altunoğlu, A. E., \& Bulgurcu Gürel, E. B. (2015). Effects of Leader-member Exchange and Perceived Organizational Support on Organizational Innovation: The Case of Denizli Technopark. Procedia-Social and Behavioral Sciences, 207, 175-181

Bernerth, J. B., Armenakis, A. A., Feild, H. S., Giles, W. F., \& Walker, H. J. (2007). Leader-member social exchange (LMSX): Development and validation of a scale. Journal of Organizational Behavior, 28(8), 979-1003. http://dx.doi.org/10.1177/1548051810366712

Bernerth, J. B., Walker, H. J., \& Harris, S. G. (2015). Rethinking the benefits and pitfalls of leader-member exchange: A reciprocity versus self-protection perspective. Human Relations, 69(3) 661-684. http://dx.doi.org/10.1177/0149206316668236

Blau, P. M. (1964). Exchange and power in social life. New York: Wiley.

Crant, J.M. (2000). Proactive behavior in organizations. Journal of Management, 26, 435- 462.

De Jong, J. \& Den Hartog, D. (2007). How leaders influence employees' innovative behaviour. European Journal of Innovation Management, 10(1), 41- 64. http://dx.doi.org/10.1108/14601060710720546

De Jong, J., \& Den Hartog, D. (2010). Measuring innovative work behaviour. Creativity and Innovation Management, 19(1), 23-36. 
Getz, I., \& Robinson, A. G. (2003). Innovate or die: Is that a fact?. Creativity and innovation management, 12(3), 130-136.

George, J. M., \& Brief, A. P. (1992). Feeling good-doing good: a conceptual analysis of the mood at work-organizational spontaneity relationship. Psychological bulletin, 112(2), 310.

Griffin, M. A., Neal, A., \& Parker, S. K. (2007). A new model of work role performance: Positive behaviour in uncertain and interdependent contexts. Academy of Management Journal, 50(2), 327-347. http://dx.doi.org/10.5465/AMJ.2007.24634438

Graen, G. B., \& Scandura, T. A. (1987). Toward a psychology of dyadic organizing. Research in organizational behavior.

Graen, G. B. (1976). Role-making process within complex organizations. In M. D. Dunnette (Ed.), Handbook of industrial and organizational psychology (pp. 1201-1245). Chicago: Rand McNally.

Hair, J. F., Black, W. C., Babin, B. J., Anderson, R. E., \& Tatham, R. L. (2006). Multivariate data analysis (6th ed.). New Jersey: Prentice Hall.

Janssen, O. (2000). Job demands, perceptions of effort-reward fairness and innovative behaviour. Journal of Occupational and Organisational Psychology, 73, 287-302. http://dx.doi.org/10.1348/096317900167038

Jing-zhou, P., \& Wen-xia, Z. (2011). Under dual perspective of work exchange and social exchange: The study of impact of LMX on affective commitment. Nankai Business Review International, 2(4), 402-417.

Katz, D. (1964). The motivational basis of organizational behavior. Systems Research and Behavioral Science, 9(2), 131-146. http://dx.doi.org/10.1002/bs.3830090206

Kheng, Y. K., June, S., \& Mahmood, R. (2013). The determinants of innovative work behavior in the knowledge intensive business services sector in Malaysia. Asian Social Science, 9(15), 47. http://dx.doi.org/10.5539/ass.v9n15p47

Lee, J. (2008). Effects of leadership and leader-member exchange on innovativeness. Journal of Managerial Psychology, 23(6), 670-687. http://dx.doi.org/10.1108/02683940810894747

Liden, R. C., Erdogan, B., Wayne, S. J., \& Sparrowe, R. T. (2006). Leader-member exchange, differentiation, and task interdependence: implications for individual and group performance. Journal of Organizational Behaviour, 27(6), 1-24. http://dx.doi.org/10.1002/job.409

Luecke, R., \& Katz, R. (2003). Managing creativity and innovation. Boston, MA: Harvard Business School Press.

Martins, E., \& Martins, N. (2002). An organisational culture model to promote creativity and innovation. SA Journal of Industrial Psychology, 28(4), 58-65.

Oukes, T. (2010). Innovative work behavior: A case study at a tire manufacturer (Bachelor's thesis, University of Twente).

Parker, S. K., Williams, H. M., \& Turner, N. (2006). Modeling the antecedents of proactive behavior at work. Journal of Applied Psychology, 91(3), 636-652. http://dx.doi.org/10.1037/0021-9010.91.3.636

Prahalad, C. K., \& Ramaswamy, V. (2012). The new frontier of experience innovation. Image.

Uhl-Bien, M. (2006). Relational leadership theory: Exploring the social processes of leadership and organizing. The Leadership Quarterly, 17(6), 654-676. http://digitalcommons.unl.edu/leadershipfacpub/19

Ramamoorthy, N., Flood, P. C., Slattery, T., \& Sardessai, R. (2005). Determinants of innovative work behaviour: Development and test of an integrated model. Creativity and Innovation Management, 14(2), 142-150.

Saudi Hospitality Sector. Report January. (2015). Retrieved from http://www.aljaziracapital.com.sa/report_file/ess/SEC-196.pdf

Scott, S. G., \& Bruce, R. A. (1994). Determinants of innovative behavior: A path model of individual innovation in the workplace. Academy of Management Journal, 37(3), 580-607. http://dx.doi.org/10.2307/256701

Sherman, K. E., Kennedy, D. M., Woodard, M. S., \& McComb, S. A. (2012). Examining the "Exchange" in Leader-Member Exchange. Journal of Leadership \& Organizational Studies, 19(4), 407-423. http://dx.doi.org/10.1177/1548051812442963

Stoffers, J. M. M., \& Van der Heijden, B. I. J. M. (2009). Towards an HRM Model predicting organisational performance by enhancing innovative work behaviour: A study among Dutch SMEs in the province of 
Limburg.

Suhaimi, I. W., \& Panatik, S. A. (2016). A literature review on relationship between leader-member exchange and innovation work behavior. Journal of Global Business and Social Entrepreneurship, 1(2), 32-41.

Subramony, M., \& Holtom, B. C. (2012). The long-term influence of service employee attrition on customer outcomes and profits. Journal of Service Research, 15(4), 460-473.

Taştan, S. B., \& Davoudi, S. M. M. (2015). An Examination of the Relationship between Leader-member Exchange and Innovative Work Behavior with the Moderating Role of Trust in Leader: A Study in the Turkish Context. Procedia - Social and Behavioral Sciences, 181, 23-32.

West, M. A., \& Farr, J. L. (1989). Innovation at work: Psychological perspectives. Social Behaviour.

Xerri, M. (2013), Workplace Relationships and the Innovative Behaviour of Nursing Employees: A Social Exchange Perspective. Asia Pacific Journal of Human Resources, 51(1), 103-123. http://dx.doi.org/10.1111/j.1744-7941.2012.00031.x

Yuan, F., \& Woodman, R. W. (2010). Innovative behaviour in the workplace: The role of performance and image outcome expectations. Academy of Management Journal, 53(2), 323-342.

\section{Copyrights}

Copyright for this article is retained by the author(s), with first publication rights granted to the journal.

This is an open-access article distributed under the terms and conditions of the Creative Commons Attribution license (http://creativecommons.org/licenses/by/4.0/). 